\title{
Recent (2001-09) Hydrologic History and Regionalization Studies in Texas-Statistical Characterization of Storms, Floods, and Rainfall-Runoff Relations
}

As part of numerous cooperative studies investigating rainfall and streamflow during 1991-2009 with the Texas Department of Transportation and Texas Commission on Environmental Quality, the U.S. Geological Survey (USGS) published about 20 reports describing either historical streamflow conditions (hydrologic history) in Texas or the results of studies involving regional rainfall and streamflow statistics (regionalization studies). Both types of studies are widely used in engineering and scientific applications. Long-term rainfall and streamflow records are essential for deriving reliable rainfall and streamflow statistics. Whereas the need for such records is regionwide, rainfall and streamflow records are site-specific. The USGS has pioneered ways to mathematically transfer site-specific rainfall and streamflow information to provide regional statistical models. In addition to publishing reports describing historical hydrologic data at many monitored locations throughout Texas, the USGS has published reports describing regional models for estimating rainfall and streamflow statistics at unmonitored locations. The primary objectives of these regionalization studies were to provide historical perspectives of streamflow conditions in Texas or estimates of specific statistics of rainfall or streamflow. Statistics such as 6-hour, 1-percent annual exceedance rainfall (a large storm) or 2-percent annual exceedance streamflow (a substantial flood) can be estimated for locations lacking sufficient direct observations of rainfall and streamflow data. This fact sheet provides a brief synopsis of 12 recent (2001-09) USGS hydrologic history and regionalization studies in Texas organized thematically and chronologically.

For more than 110 years, the National Weather Service (NWS) and USGS have operated independent monitoring and data-collection networks of rainfall (NWS) and streamflow (USGS) stations at different locations; seldom are NWS and USGS data-collection stations collocated or even located in close proximity. Each agency separately publishes these data, including hourly and daily rainfall and annual peak and daily mean streamflow, for more than 10,000 stations throughout the United States and more than 1,000 stations throughout

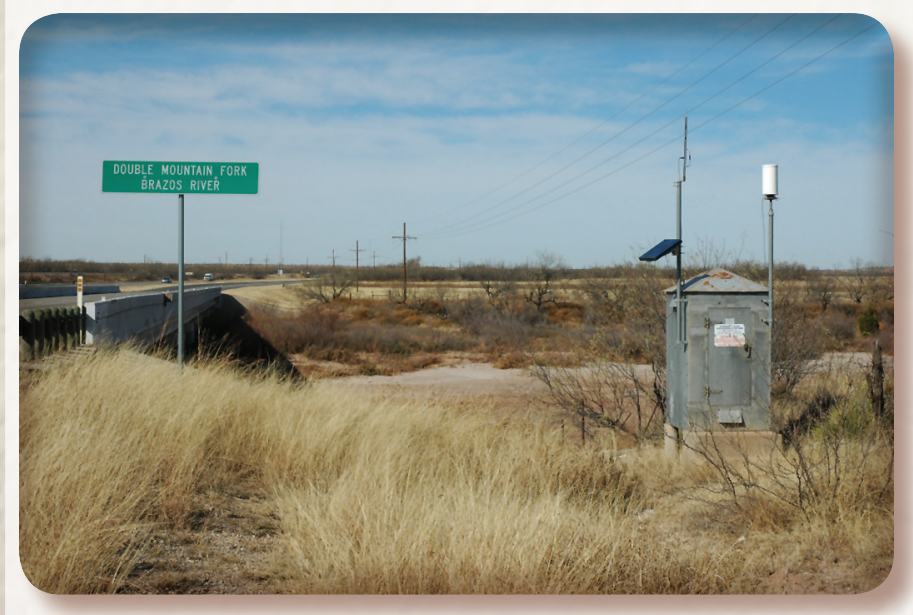

U.S. Geological Survey streamflow-gaging station 08079600 Double Mountain Fork Brazos River at Justiceburg, Texas.
Texas. The hydrometeorological networks of the NWS and USGS are like "information archipelagos"-isolated islands of information and analysis - because the data collected are associated with specific geographic locations, and knowledge gaps exist in the gulf between stations (the ungaged locations). The data for each station also are unique in both date of observation and the period of record. In the context used herein, rainfall data are strictly point values and represent the aggregate influence of climatic and weather variation at each station. Conversely, streamflow data at each station represent hydrologic responses to a multitude of spatially integrative processes in the watersheds converting rainfall into streamflow.

Cursory review of NWS and USGS data shows that the climate and physiography of Texas vary considerably across the State. Accordingly, climatic and physiographic factors cause substantial temporal and spatial variability as well as a disproportionate number of extreme low- and high-magnitude rainfall and runoff events compared to most States. For example, in Texas, rainfall-generation processes might readily produce as much as 2 orders-of-magnitude range in a rainfall statistic during the lifetime of a station, whereas streamflow-generation processes might readily produce 3 to 4 orders-of-magnitude range. Such substantial variation makes reliable use of data obtained from a single to even a few stations difficult; because of the small number of data points compared to the size of the area and the variability in streamflow and rainfall, developing an accurate understanding of the hydrology for a region can be daunting.

Regionalization is a mathematical and statistical approach that can be used to mitigate the problems posed by limited rainfall and streamflow data that vary greatly in magnitude. Regionalization is a concept in which data are statistically combined and transferred from the station network to similar but unmonitored or ungaged locations. The concept also provides for "substitution of space for time" and provides for more reliable estimates of extreme low- or high-magnitude events. Although not limited to such, many hydrologic regionalization studies rely on statistically derived relations between a statistic of interest and watershed characteristics such as location, drainage area, and mean annual rainfall. These empirical relations, which often are defined by linear regression, provide equations from which estimation of the statistic can be made using the watershed characteristics of the location or stream reach being evaluated.

\section{A Public Need for Regionalization Studies}

The statistical procedures derived during regionalization studies can be used by scientists, engineers, and decision makers to understand the potential for large storms and floods, particularly in ungaged areas, and to make informed decisions pertaining to water resources and public and private infrastructure. Specifically, regionalization studies of rainfall and streamflow can be used for (1) flood-plain management; (2) objective assessment of flood risk; (3) cost-effective and riskcommensurate design of dams, levees, and other flood-control structures; (4) design of roads, bridges, and culverts; (5) design of stormwater detention systems and other watershed best management practices; and (6) a wide range of regulatory criteria and decisions related to water quantity and quality. 


\section{Studies of Rainfall Statistics in Texas}

The USGS has published four reports (listed chronologically herein) describing rainfall statistics in Texas: (1) The "interoccurrence atlas" provides statewide contour maps of intervals, measured in days, between those days for which daily rainfall exceeded selected thresholds, such as 1 inch. (2) The "depth-duration frequency (DDF) atlas" is a statewide source for annual maxima-design storms, which are used as inputs to hydrologic models. (3) The "cumulative-rainfall hyetographs from 1959-86 storm data" report describes temporal distributions of rainfall within storms for use in applying rainfall-runoff relations in Texas. (4) The "storm statistics professional paper" is a statewide source for more frequent rainfall (storms) than the conceptually distinct rainfall statistics of the DDF atlas. The storm statistics professional paper provides a framework based on maps, tables, and probability distributions to estimate storm statistics, including storm interevent times, distributions of storm depths, and distributions of storm durations. The use of probabilistic approaches to design small runoffcontrol structures requires such rainfall statistics.

1. Asquith, W.H., and Roussel, M.C., 2003, Atlas of interoccurrence intervals for selected thresholds of daily precipitation in Texas: USGS Water-Resources Investigations Report 03-4281, 204 p.

2. Asquith, W.H., and Roussel, M.C., 2004, Atlas of depth-duration frequency of precipitation annual maxima for Texas: USGS Scientific Investigations Report 2004-5041, 106 p.

3. Williams-Sether, Tara, Asquith, W.H., Thompson, D.B., Cleveland, T.G., and Fang, Xing, 2004, Empirical, dimensionless, cumulative-rainfall hyetographs developed from 1959-86 storm data for selected small watersheds in Texas: USGS Scientific Investigations Report 2004-5075, 125 p.

4. Asquith, W.H., Roussel, M.C., Cleveland, T.G., Fang, Xing, and Thompson, D.B., 2006, Statistical characteristics of storm interevent time, depth, and duration for eastern New Mexico, Oklahoma, and Texas: USGS Professional Paper 1725, 299 p.

\section{Studies of Flood-Flow Magnitude in Texas}

The USGS has published three reports (listed chronologically herein) describing instantaneous flood-flow magnitudes in Texas: (1) The "effects of regulation on L-moments" report presents the effects of flood control (reservoirs) on annual peak-streamflow statistics (mean, variation, and others); this study can be useful in hydrologic evaluation of flood potential in regulated watersheds and river basins. (2) The "alternative regression equations for estimation of annual peak-streamflow frequency" report provides several procedures for estimating the flood magnitude for undeveloped (rural or natural) watersheds across Texas. In the studies summarized by the second and third reports, many equations of the form $Q_{T}=a A^{b}$ were developed for the $T$-year recurrence interval of streamflow $(Q)$ for contributing drainage area (A), with empirically determined coefficients $a$ and $b$. (3) The "regression equations for estimation of annual peak-streamflow" report is similar to the second report; it also summarizes results obtained by using the regression equations developed for the second report and makes comparisons among results to those published in the second report.

1. Asquith, W.H., 2001, Effects of regulation on L-moments of annual peak streamflow in Texas: USGS Water-Resources Investigations Report 01-4243, 66 p., 2 pl.

2. Asquith, W.H., and Thompson, D.B., 2008, Alternative regression equations for estimation of annual peak-streamflow frequency for undeveloped watersheds in Texas using PRESS minimization: USGS Scientific Investigations Report 2008-5084, 40 p.

3. Asquith, W.H., and Roussel, M.C., 2009, Regression equations for estimation of annual peak-streamflow frequency for undeveloped watersheds in Texas using an L-moment-based, PRESSminimized, residual-adjusted approach: USGS Scientific Investigations Report 2009-5087, 48 p.

\section{Studies of Rainfall-Runoff Relations in Texas}

The USGS has published two reports (listed chronologically herein) describing rainfall-runoff relations in Texas: (1) The "statewide analysis of the drainage-area ratio method" report describes a drainagearea ratio method for transferring streamflow data from a station to another location on the basis of the proportionality of an exponential ratio of drainage areas to the ratio of streamflow. The exponent is a function of streamflow percentile and changes across the low- to high-flow conditions. (2) The "constant-loss model for unit hydrograph modeling" report presents a storm-oriented modeling approach that is a variation of the "unit hydrograph method." The unit hydrograph is the streamflow hydrograph generated by one unit of excess rainfall, which is uniformly distributed across the watershed for a specified duration. The unit hydrograph method is a widely used hydrologic model. The techniques presented in this study include the application of an initial abstraction (loss) of rainfall at inception of the storm and subsequent constant loss (infiltration and other) used in conjunction with a gamma distribution model of a unit hydrograph that is parameterized by timeto-peak and a curvature factor.

1. Asquith, W.H., Roussel, M.C., and Vrabel, Joseph, 2006, Statewide analysis of the drainage-area ratio method for 34 streamflow percentile ranges in Texas: USGS Scientific Investigation Report 2006-5286, 34 p., 1 appendix.

2. Asquith, W.H., and Roussel, M.C., 2007, An initial-abstraction, constant-loss model for unit hydrograph modeling for applicable watersheds in Texas: USGS Scientific Investigations Report 2007-5243, 82 p.

\section{Studies of Streamflow History in Texas}

The USGS has published three "streamflow history" reports (listed chronologically herein) that provide summaries and depictions of selected statistics of daily mean streamflow in Texas. Various histories of surface-water resources in Texas, including monthly, annual, and greater time scales collectively, are shown. These studies provide hydrologic information from individual watershed to river basin scales by conveying the history of zero-flow potential, minimum, maximum, mean, median, harmonic mean, and inter- and intra-annual variation of streamflow for more than 600 watersheds in Texas.

1. Asquith, W.H., Vrabel, Joseph, and Roussel, M.C., 2007, Summary of percentages of zero daily mean streamflow for 712 USGS streamflow-gaging stations in Texas through 2003: USGS Data Series 247, 721 p.—online only http://pubs.usgs.gov/ $d s / 2007 / 247 /$.

2. Asquith, W.H., Vrabel, Joseph, and Roussel, M.C., 2007, Summary of annual mean, maximum, minimum, and L-scale statistics of daily mean streamflow for 712 USGS streamflow-gaging stations in Texas through 2003: USGS Data Series 248, 721 p.online only http://pubs.usgs.gov/ds/2007/248/.

3. Asquith, W.H., and Heitmuller, F.T., 2008, Summary of annual mean and annual harmonic mean statistics of daily mean streamflow for 620 USGS streamflow-gaging stations in Texas through water year 2007: USGS Data Series 372, 1,259 p.- online only http://pubs.usgs.gov/ds/372/.

\section{William H. Asquith}

Additional Information: More information about the Texas Department of Transportation Research and Technology Implementation Office program is available at http://www.txdot.gov/txdot_library/ publications/research.htm. More information about the Texas Commission on Environmental Quality is available at $h t t p: / / w w w . t c e q$. state.tx.us/. More information about the National Weather Service is available at http://www.nws.noaa.gov/. More information about the USGS and its publications is available at $h t t p: / / w w w . u s g s . g o v /$ and http://pubs.er.usgs.gov/, respectively. Photograph courtesy of the author. 